\title{
Kajian Literatur: Faktor-Faktor yang Mempengaruhi Partisipasi Pasien dalam Keselamatan Pasien
}

\author{
Wening Putri Susanti ${ }^{1}$, Devi Nurmalia ${ }^{{ }^{*}}$ \\ ${ }^{1}$ Departemen Ilmu Keperawatan Fakultas Kedokteran, Universitas Diponegoro, Semarang \\ Indonesia \\ devinurmalia@fk.undip.ac.id
}

\begin{abstract}
Introduction: Patient participation is globally recognized as one of the main factors for promoting quality and safety of health services. Active patient participation is a patient safety priority for health care. Yet, patients and their preferences are less understood. Literature review related to determinants of patient participation last five years is limited. The aim of this study was to determine the factors that influence patients to participate in patient safety.

Methods: This study used a literature review method by searching online data. Literature was searched through electronic database such as EBSCOhost, Science Direct, and Scopus. The inclusion criteria of article were respondent to the article found are inpatient and nurse, full text articles and publication years from 2015 to 2019.

Results: Search results found four articles were eligible to be reviewed. This review indicates that there are two factors that influence patient participation in patient safety, including factors from the patient's side and factors from the nurse's side.

Conclusion: These results reinforce that creating patient safety requires the collaboration of all parties, not only from the nurse but also from the patient. Patient involvement needs to be further investigated regarding the extent of patient participation in patient safety.
\end{abstract}

Keywords: Factor Affect, Patient Participation, Patient Safety.

\begin{abstract}
Abstrak
Pendahuluan: Partisipasi pasien diakui secara global sebagai faktor utama dalam mempromosikan kualitas dan keamanan pelayanan kesehatan. Partisipasi aktif pasien merupakan prioritas utama dalam keselamatan pasien. Telaah artikel terkait faktor-faktor yang mempengaruhi partisipasi pasien lima tahun terakhir masih terbatas. Penelitian ini bertujuan untuk mengetahui faktor-faktor yang mempengaruhi pasien untuk berpartisipasi dalam keselamatan pasien.

Metode: Penelitian ini menggunakan metode literatur review dengan penelusuran data online. Data base elektronik yang digunakan antara lain adalah EBSCOhost, Science Direct, dan Scopus. Kriteria inklusi yang digunakan antara lain responden pada artikel adalah pasien yang sedang menjalani rawat inap dan perawat, artikel full text, dan dipublikasikan antara tahun 2015-2019.

Hasil: Terdapat empat artikel yang sesuai dengan kriteria inklusi. Hasil telaah menunjukkan bahwa terdapat dua faktor yang mempengaruhi partisipasi pasien dalam keselamatan pasien antara lain faktor dari sisi pasien dan faktor dari sisi perawat.

Kesimpulan: Hasil ini memperkuat bahwa menciptakan keselamatan pasien dibutuhkan keterlibatan dari semua pihak tidak hanya dari perawat saja tetapi juga dari pasien. Keterlibatan pasien perlu diteliti lebih lanjut terkait sejauh mana keterlibatan pasien dalam keselamatan pasien.
\end{abstract}

Kata kunci: Faktor yang Mempengaruhi, Partisipasi Pasien, Keselamatan Pasien. 


\section{PENDAHULUAN}

Keselamatan pasien menjadi fokus utama pemerintah dan juga penyedia layanan kesehatan secara nasional maupun internasional. Keselamatan pasien tidak akan lengkap jika sudut pandang dan keterlibatan pasien tidak diperhitungkan (Hovey et al., 2010; Vincent \& Coulter, 2002).

Pasien dapat memberikan keterlibatannya dalam berbagai cara. Pasien dapat membantu memastikan bahwa obat yang diberikan digunakan dengan aman, berpartisipasi dalam inisiatif pengendalian infeksi, melaporkan insiden keselamatan pasien, memonitor perawatan dan memberikan informasi serta saran untuk mengembangkan proses pelayanan kesehatan yang lebih aman (Berger et al., 2013; Coulter \& Ellins, 2007, Vincent \& Coulter, 2002).

Penelitian sampai saat ini menunjukkan manfaat nyata bagi pasien yang berpartisipasi dalam perawatan. Partisipasi pasien dalam meningkatkan praktik keselamatan di rumah sakit adalah konsep yang meyakinkan (Berger et al., 2013; Coulter \& Ellins, 2007; Longtin et al., 2010), terutama ketika pasien mengelola pengobatan sendiri (Hall et al., 2010). Satu studi di Amerika Serikat menemukan, risiko mengalami efek samping dalam pengobatan menjadi berkurang, ketika partisipasi pasien diterapkan (Weingart et al., 2011).

$$
\text { Partisipasi pasien juga }
$$

meningkatkan kepuasan dan pasien (Dudas et al., 2013; Ho“ glund et al., 2010). Pendekatan yang berpusat pada pasien, termasuk partisipasi pasien, juga meningkatkan kepuasan pasien (Dwamena et al., 2012) dan kualitas perawatan yang dirasakan (Slatore, 2010; Weingart et al.,
2011). Akhirnya, melibatkan pasien dalam perawatan dapat meningkatkan kondisi, khususnya fungsi pasien dalam aktivitas kehidupan sehari-hari (Ekman et al., 2012). Mendorong partisipasi pasien dalam asuhan keperawatan, sangat bermanfaat bagi pasien.

Partisipasi pasien dalam keselamatan masih menemui beberapa hambatan yang berasal dari tenaga kesehatan maupun pasien. Model paternalistis antara pasien dan tenaga kesehatan yang terjadi membuat pasien sungkan untuk berpartisipasi (Longtin et al., 2010). Penelitian Silfa dan tim menunjukkan bahwa partisipasi pasien dalam keselamatan pasien tergolong masih rendah $(61,33 \%)$ dari standar KARS yang menargetkan bahwa 75\% keterlibatan dalam keselamatan pasien (Silfa, Hardisman, \& Pabuti, 2018). Tidak ada data lain di Indonesia yang berkaitan dengan partisipasi pasien dalam keselamatan pasien. Hwang, Kim, \& Chin (2019) menilai partisipasi pasien dalam keselamatan pasien dinilai masih rendah $(29,6 \%)$.

Ada beberapa penelitian tentang partisipasi pasien dalam perawatan, dengan fokus khusus pada keselamatan pasien (Berger et al., 2013; Hall et al., 2010; Peat et al., 2010). Penelitian sebelumnya dilakukan lebih dari 5 tahun yang lalu dan kemungkinan pendekatan partisipasi pasien telah berkembang terutama dalam kaitannya dengan keselamatan pasien. Tinjuan yang telah dilakukan, berupaya melihat partisipasi pasien secara umum dan strategi untuk meningkatkan partisipasi. Tinjauan yang ada belum pernah membahas terkait faktor-faktor yang mempengaruhi partisipasi pasien. Tinjauan lebih lanjut terkait faktor-faktor yang mempengaruhi 
patisipasi pasien diperlukan lebih lanjut untuk mengevaluasi prespektif dan perilaku pasien dan perawat terhadap partisipasi pasien.

Penelitian ini bertujuan untuk mengetahui faktor-faktor yang mempengaruhi pasien untuk berartisipasi dalam keselamatan pasien. Penelitian ini diharapkan dapat memberi manfaat bagi profesi, rumah sakit, institusi pendidikan, bagi penelitian dan bagi pasien. Hasil penelitian ini diharapkan mampu untuk mendorong peningkatan kesadaran tenaga kesehatan untuk mendorong partisipasi pasien dalam keselamatan pasien, mengembangkan strategi untuk memberdayakan pasien agar lebih berpartisipasi dalam keselamatan, menjadi referensi mengenai partisipasi pasien dalam keselamatan, dan menjadi sumber pengetahuan bagi pasien untuk mengetahui pentingnya partisipasi pasien dalam keselamatan.

\section{METODE}

Penelitian ini menggunakan metode kajian literatur dengan penelusuran data online. Penelusuran data online menggunakan database elektronik antara lain EBSCOhost, Scopus dan Science Direct. Artikel yang digunakan adalah artikel hasil penelitian kuantitatif dan kualitatif dari jurnal yang terindeks SCOPUS dengan rentang publikasi 20152019 dan sesuai dengan daftar istilah yang digunakan dan dapat diakses fulltext. Kata kunci yang digunakan dalam Bahasa Inggris adalah patients participation, patients involement, dan patient safety. Kata kunci tersebut digabungkan dengan menggunakan operator seperti "OR", dan “AND”. Hasil pencarian literatur diperoleh sebanyak 515 artikel, kemudian dipilah sesuai kriteria penelitian sehingga terdapat empat artikel yang digunakan untuk ditelaah dalam artikel ini (Gambar 1).

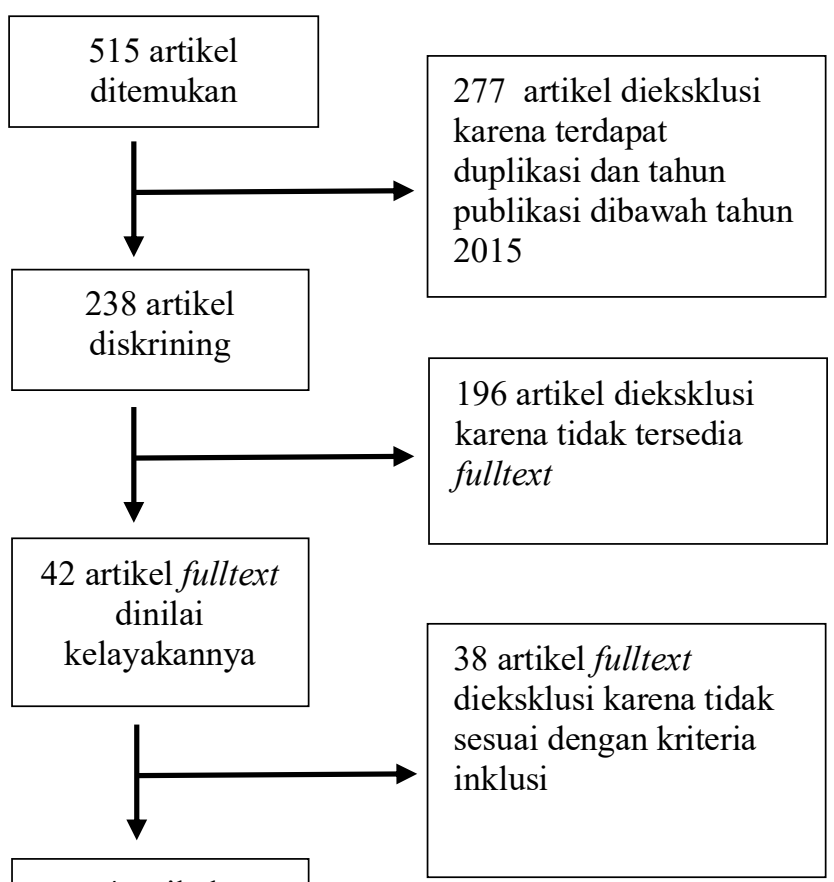

dilakukan review

Gambar 1. Diagram alur pencarian artikel

\section{HASIL}

Empat artikel yang telah terpilih untuk ditelaah terindeks SCOPUS dengan kualifikasi Q1 dan Q2. Seluruh artikel terpublikasi dari tahun 2016-2019 yaitu tahun 2016 (satu artikel), 2017 (satu artikel), dan 2019 (dua artikel). Identitas artikel ditunjukkan dalam Tabel 1 .

Telaah literatur mengenai partisipasi pasien dalam keselamatan menghasilkan dua tema faktor yang mempengaruhi partisipasi pasien dalam keselamatn pasien, yakni faktor yang mempengaruhi dari sisi pasien dan perawat. Faktor yang mempengaruhi partisipasi pasien dalam keselamatan dari sisi pasien antara lain adalah tiga faktor pendukung serta dua faktor penghambat. Sementara 
faktor yang mempengaruhi partisipasi pasien dalam keselamatan dari sisi perawat adalah tiga faktor pendukung serta satu faktor penghambat. Hasil telaah artikel menjelaskan faktor yang mempengaruhi partisipasi dapat berasal dari pasien maupun dari perawat, yang dapat mendukung ataupun menghambat partisipasi pasien dalam keselamatan. Faktor pendukung yang berasal dari pasien antara lain pengalaman pasien, pengetahuan pasien, persepsi pasien mengenai partisipasi. Faktor penghambat, antara lain status kesehatan pasien dan sikap pasien terhadap partisipasi.

Hasil dari faktor pendukung partisipasi pasien yang dilihat dari sisi perawat adalah model patient-centred care yang diterapkan asuhan keperawatan, pertukaran informasi yang dilakukan perawatan dan juga iklam keselamatan dalam lingkungan kerja. Ketidakseimbangan kekuatan yang dirasakan pasien ke perawat merupakan faktor yang dapat menghambat partisipasi pasien. Hasil secara detail ditunjukkan pada Tabel 2.

\section{PEMBAHASAN}

Tiga studi menggunakan penelitian kuantitatif dan satu studi dengan desain kualiatif. Artikel dengan pendekatan kuantitatif ditarik kesimpulan secara induktif dengan membaca berkali-kali bagian hasil. Artikel dengan pendekatan kualitatif disimpulkan secara deduktif dengan melihat tema-tema yang dihasilkan. Hasil telaah literatur yang telah dilakukan, ditemukan hasil bahwa terdapat dua tema faktor yang dapat mempengaruhi partisipasi pasien dalam keselamatan pasien yakni dari sisi pasien dan dari sisi perawat.
Faktor yang Mempengaruhi Partisipasi Pasien dalam Keselamatan Pasien dari Sisi Pasien

\section{Faktor Pendukung}

Faktor partisipasi pasien dalam keselamatan pasien dari sisi pasien terdiri dari pengalaman pasien mengenai kesalahan, pengetahuan pasien, dan persepsi pasien mengenai partisipasi. Pengalaman mengenai kesalahan dapat mempengaruhi partisipasi pasien dalam keselamatan. Merja et al. (2019) menemukan bahwa kelompok pasien yang tidak memiliki pengalaman kesalahan menunjukkan hasil yang positif dalam peningkatan partisipasi pasien dalam keselamatan pasien. Pasien menunjukkan keinginan untuk berpartisipasi dalam keselamatan meskipun sebelumnya tidak memiliki pengalaman terhadap kesalahan. Hal berarti pasien menganggap kesalahan sebagai sesuatu yang wajar dan dapat dicegah bergantung pada strategi untuk mendorong partisipasi pasien dalam keselamatan (Sahlström et al., 2019). Banyaknya pengalaman mengenai insiden keselamatan pasien yang dialami pasien akan meningkatkan keikutsertaan mereka dalam keselamatan (Davis et al., 2007). Pasien juga dapat dilibatkan dalam pembuatan system mengenai strategi pengembangan pengurangan risiko kesalahan pengobatan (Schwappach, Frank, \& Hochreutener, 2011).

Faktor kedua adalah pengetahuan pasien. Pasien mendapatkan kesempatan untuk berpartisipasi dalam upaya keselamatan dalam perawatannya sendiri salah satunya dengan diberikan kebebasan menentukan keputusan sendiri, namun kebebasan tersebut perlu diimbangi dengan pengetahuan pasien agar pasien dapat 
menentukan keputusan yang terbaik. Pengetahuan mengenai dasar hukum keselamatan pasien juga diperlukan untuk menjadikan pasien mengerti hak-hak pasien agar tidak terjadi ketidakpedulian dan berbagai bentuk pelanggaran terhadap hak pasien selama dirawat (Silfa, Hardisman, \& Pabuti, 2018). Pengetahuan dan juga pengalaman pasien mengenai keselamatan dapat digunakan secara efektif untuk meningkatkan partisipasi pasien dalam keselamatan pasien (Sahlström et al., 2016). Pengetahuan yang diinformasikan dengan baik akan memberikan kepercayaan diri pada kemampuan diri pasien untuk membuat keputusan (Longtin et al., 2010). Pasien akan lebih berinisiatif untuk berpartisipasi dalam keselamatan pasien serta mampu memantau dan mendeteksi kesalahan praktik dalam perawatannya apabila memiliki pengetahuan yang baik mengenai keselamatan pasien dan juga familier dengan perawatan yang didapatnya (Davis et al., 2007).

Faktor ketiga adalah persepi pasien. Persepsi pasien mengenai partisipasi pasien mampu mempengaruhi partisipasi pasien dalam keselamatan pasien. Persepsi pasien terhadap partisipasi pasien dalam keselamatan dipengaruhi oleh ketertarikan pasien, motivasi pasien terhadap partisipasi, dan kepercayaan pasien terhadap tenaga kesehatan (Sahlström et al. 2016). Pasien yang memiliki persepsi negatif pada partisipasi menunjukan hasil yang rendah untuk berpartisipasi dalam keselamatan. Beberapa hal yang dapat mempengaruhi persepsi berupa faktor internal adalah prasangka, keinginan atau harapan, perhatian, proses belajar, keadaan fisik, kejiwaan, nilai, kebutuhan, minat dan motivasi (Silfa, Hardisman, \& Pabuti, 2018). Pasien menaruh minat untuk berpartisipasi dalam keselamatan, dimana mereka merasa tidak puas hanya menjalani peran sebagai pihak yang menerima tanpa ada diskusi terbuka dengan mereka (Ringdal et al. 2017).

\section{Faktor Penghambat}

Faktor penghambat partisipasi pasien dalam keselamatan pasien dari sisi pasien meliputi status kesehatan pasien dan sikap pasien terhadap partisipasi. Status kesehatan pasien dinilai menjadi faktor yang mempengaruhi partisipasi pasien sesuai dengan kondisi kesehatannya. Pada penelitian yang dilakukan Merja dan tim, mengungkapkan bahwa status kesehatan pasien mempengaruhi seberapa mampu pasien berpartispasi dalam keselamatan (Sahlström et al., 2016). Pasien merasa terkadang tidak mampu berpartisipasi dalam keselamatan maupun perawatan dikarenakan penyakitnya. Hal ini menyebabkan pasien merasa tidak termotivasi dan lebih cenderung pasif (Ringdal et al., 2017). Pasien dengan kondisi penyakit yang ringan lebih cenderung aktif berpartisipasi dalam keselamatan dibanding dengan pasien yang memiliki penyakit berat. Contohnya adalah pasien yang menderita HIV tanpa gejala pembert lebih berpartisipasi aktif dibanding dengan pasien HIV yang sudah mulai menunjukkan gejala kelemahan fisik (Davis et al. 2007).

Sikap pasien terhadap partisipasi pasien dapat mempengaruhi praktik partisipasi pasien dalam keselamatan. Kecenderungan sikap pasien ketika dirawat di rumah sakit adalah menyerahkan pengambilan keputusan kepada perawat. Pasien berpikir bahwa tenaga kesehatan lebih mengetahui apa yang terbaik untuk mereka. Hal ini menghambat pasien dalam 
proses pengambilan keputusan, termasuk dalam meningkatkan keamanan pada perawatan kesehatan yang pasien terima (Sahlström et al., 2016). Sikap pasien yang aktif dalam keselamatan bergantung pada kemauan, penerimaan terhdap peran yang baru oleh pasien (Longtin et al., 2010), dan rasa waspada yang timbul untuk kemajuan pasien (Vaismoradi, Jordan, \& Kangasniemi, 2015). Pasien akan memiliki keinginan jika menerima partisipasi pasien dalam keselamatan menjadi sebuah hal yang normal dan wajar. Perawat perlu mengerti untuk memberdayakan pasien dalam berpartisipasi pada keselamatan, menjadikan pasien sebagai partner yang memiliki kontrol terhadap diri sendiri. Ketika pasien menemukan bahwa perawat atau tenaga kesehatan tidak membangun hubungan kemitraan dengan pasien atau meninggalkan pendapat pasien, pasien akan kehilangan rasa percaya diri dan menolak bersikap kooperatif dan kontak di masa depan, yang berarti bahwa pasien akan kembali pada sikap pasif (Vaismoradi, Jordan, \& Kangasniemi, 2015).

\section{Faktor yang Mempengaruhi Partisipasi Pasien dalam Keselamatan Pasien dari Sisi Perawat}

\section{Faktor Pendukung}

Terdapat tiga faktor pendukung partisipasi pasien dalam keselamatan pasien dari sisi perawat yaitu perawat yang menerapkan Model Patient-Centered Care, pertukaran informasi perawat, dan iklim keselamatan dalam lingkungan kerja. Perawat yang menerapkan model Patient Centered care dengan baik menjadi faktor yang mempengaruhi partisipasi pasien dalam keselamatan. Perawat dengan tingkat kompetensi yang tinggi terhadap Patient
Centered care, akan mendukung promosi mengenai upaya partisipasi pasien dimana perawat menilai keikutsertaan pasien adalah penting (Hwang, Kim, \& Chin, 2019). Pengetahuan mengenai keselamatan pasien dari tenaga kesehatan dan pasien juga perlu ditingkatkan untuk meningkatkan perhatian yang baik dalam perubahan sikap, promosi kolaborasi interprofessional dan memberikan atmosper terbuka untuk partisipasi pasien (Sahlström et al., 2016). Perawat perlu mengetahui bahwa pasien dapat berkontribusi pada komunikasi klinik, menunjukkan minat dalam mendukung hak pasien dalam asuhan, memandang pilihan pasien sebagai inti dari partisipasi, dan mengembangkan minat pasien untuk memegang kendali. Perawat yang dapat mendampingi dan membangun suasana yang baik untuk berdiskusi sangat diperlukan dalam upaya menjadikan pasien yang dapat memegang kendali dengan penuh tanggung jawab. Perawat yang mampu membangun kolaborasi yang baik dengan pasien mampu menciptakan system kesehatan yang yang aman dan selamat (Vaismoradi, Jordan, \& Kangasniemi 2015).

Pertukaran informasi yang terjadi antara perawat dan pasien menjadi faktor kedua yang dapat mendukung partisipasi pasien dalam keselamatan pasien. Perawat yang menginformasikan dan mendorong partisipasi pasien dan memberikan informasi yang penting dengan cara yang mudah dipahami dalam waktu yang tepat dapat mendorong partisipasi pasien dalam keselamatan. Hal ini dapat mempengaruhi kemampuan pasien dalam mengidentifikasi kesahalan (Sahlström et al., 2019). Perawat dapat menggunakan kemampuannya dalam berkomunikasi dan membangun hubugan dengan pasien, sehingga dapat terbangun 
suasana yang nyaman untuk berdiskusi dengan saling menghormati. Pasien yang mendapat suasana yang membangun dan informasi yang cukup akan timbul keinginan untuk berpartisipasi dalm perawatan dan juga keselamatannya (Hor et al., 2013). Informasi yang dapat diberikan kepada pasien untuk meningkatkan partisipasi pasien dalam keselamatan berupa infromasi mengenai porsi pasien dapat berpartisipasi dalam aktifitas keselamatan, meningkatkan kapasitas pasien untuk menerima tanggung jawab, dan perubahan perilaku (Vaismoradi, Jordan, \& Kangasniemi, 2015).

Iklim keselamatan yang diterapkan dalam lingkungan kerja menjadi faktor terakhir yang mendukung partisipasi pasien. Perawat yang bekerja dalam iklim keselamatan yang tinggi memiliki pengalaman mengenai partisipasi pasien dalam keselamatan pasien yang baik. Lingkungan yang memprioritaskan keselamatan pasien adalah penting dalam meningkatkan partisipasi pasien. Perawat yang bekerja pada lingkungan kerja dengan iklim keselamatan yang kuat akan memprioritaskan dan menilai keselamatan pasien, yang bertujuan untuk mengurangi dan mencegah kesalahan dan kejadian yang tidak diinginkan. Perawat tersebut akan melibatkan pasien dalam mengukur keselamatan pasien (Hwang, Kim, \& Chin, 2019). Perawat yang bekerja pada iklim keselamatan yang baik akan menyadari bahwa kontribusi pasien adalah umpan balik yang penting untuk praktik keselamatan pada tim tenaga kesehatan. Umpan balik dari pasien ini harus dianggap menjadi komponen yang normal, sehingga dapat dijadikan sumber daya berharga untuk pertukaran informasi baik dalam tim kesehatan maupun untuk penyedia layanan kesehatan (Vaismoradi, Jordan, \& Kangasniemi, 2015).

\section{Faktor Penghambat}

Faktor penghambat partisipasi pasien dalam keselamatan pasien dari sisi perawatan adalah ketidakseimbangan kekuatan. Ketidakseimbangan kekuatan antara pasien dengan tenaga kesehatan menjadi salah satu faktor yang dapat menghambat pasien untuk berpartisipasi dalam keselamatan. Pasien merasa kurangnya pengetahuan dan pemahaman mengenai kondisi kesehatannya menghalangi partisipasi, sehingga terjadi ketidakseimbangan kekuatan diantara tenaga kesehatan dengan pasien. Pasien merasa mereka tidak didengarkan, tidak dilibatkan, dan tidak diterima, sehingga mereka merasa dihalangi dan rendah diri untuk berpartisipasi (Ringdal et al., 2017). Ketidakseimbangan kekuatan ini dapat disebabkan karena tenaga kesehatan tidak ingin untuk membagi kekuatan mereka dalam membuat keputusan karena menganggap pasien tidak mampu untuk melakukan hal tersebut (Longtin et al., 2010). Tenaga kesehatan yang menerima usaha pasien dalam keselamatan, tidak hanya membantu dalam mencegah bahaya namun juga menguatkan kapasitas pasien dan tenaga kesehatan dalam kolaborasi di masa depan (Joseph-Williams, Elwyn, \& Edwards, 2014).

\section{KESIMPULAN DAN SARAN}

Telaah literatur ini menggambarkan berbagai faktor yang mempengaruhi partisipasi pasien dalam keselamatan pasien. Faktor yang mempengaruhi dari sisi pasien antara lain adalah pengalaman mengenai kesalahan, pengetahuan pasien, persepsi pasien, status kesehatan dan juga 
sikap pasien. Faktor yang mempengruhi partisipasi pasien dalam keselamatan dari sisi perawat antara lain adalah perawat yang menerapkan Model Patient-Centered Care, pertukaran informasi yang dilakukan perawat, iklim keselamatan pada lingkungan kerja, dan ketidakseimbangan kekuatan. Ada implikasi untuk partisipasi pasien dalam praktik, pendidikan dan penelitian untuk mengatasi tantangan yang dihadapi di bangsal medis. Pasien harus didorong untuk berpartisipasi aktif dalam penilaian dan perencanaan perawatan. Selanjutnya, perawat mungkin mendapat manfaat dari merefleksikan pandangannya tentang perawatan yang berpusat pada pasien, dan bagaimana hal ini berdampak pada keterlibatan pasien. Mendapatkan pemahaman yang lebih baik dari atribut inti dari partisipasi pasien dapat membantu perawat menerapkan strategi yang ditargetkan untuk mempromosikan partisipasi. Pendidikan lebih lanjut untuk perawat pada pendekatan yang berpusat pada pasien untuk perawatan dan keterampilan interpersonal mungkin diperlukan untuk meningkatkan partisipasi pasien di bangsal. Penelitian lebih lanjut diperlukan untuk menemukan cara untuk mengatasi hambatan partisipasi pasien. Penelitian lebih lanjut dengan menggunakan data observasi ataupun wawancara dapat membantu memberikan informasi strategi untuk meningkatkan partisipasi pasien sehingga peningkatan partisipasi pasien dapat dilakukan dengan pendekatan sebagai peningkatan praktik, kegiatan pendidikan atau penelitian.

Tabel 1. Identitas Jurnal

\begin{tabular}{|c|c|c|c|c|c|}
\hline No. & Nama dan Tahun & Judul Artikel & Nama Jurnal & $\begin{array}{l}\text { Data Base } \\
\text { Elektronik }\end{array}$ & $\begin{array}{c}\text { Kualifikasi } \\
\text { Jurnal }\end{array}$ \\
\hline 1. & $\begin{array}{l}\text { Merja Sahlstrom, } \\
\text { Pirjo Partanen, } \\
\text { Cheryl Rathert, } \\
\text { Hannele Turunen } \\
\text { (2016) }\end{array}$ & $\begin{array}{l}\text { Patient Participation } \\
\text { in Patient Safety Still } \\
\text { Mising: Patient } \\
\text { Safety Experts Views }\end{array}$ & $\begin{array}{l}\text { International } \\
\text { Journal of } \\
\text { Nursing } \\
\text { Practice }\end{array}$ & EBSCOhost & $\begin{array}{l}\text { Q2 pada } \\
\text { Nursing } \\
\text { (Miscellaneous) }\end{array}$ \\
\hline 2. & $\begin{array}{l}\text { Mona Ringdal, } \\
\text { Wendy } \\
\text { Chaboyer, } \\
\text { Kerstin Ulin, } \\
\text { Tracey Bucknall, } \\
\text { Lena Oxelmark } \\
\text { (2017) }\end{array}$ & $\begin{array}{l}\text { Patient Preferences } \\
\text { for Participation in } \\
\text { Patient Care and } \\
\text { Safety Activities in } \\
\text { Hospital }\end{array}$ & $B M$ & EBSC & $\begin{array}{l}\text { Q1 pada } \\
\text { Nursing } \\
\text { (Miscellaneous) }\end{array}$ \\
\hline 3. & $\begin{array}{l}\text { Merja Sahlstrom, } \\
\text { Pirjo Partanen, } \\
\text { Mina Azimirad, } \\
\text { Tuomas } \\
\text { Selander, } \\
\text { Hannele Turunen } \\
(2019)\end{array}$ & $\begin{array}{l}\text { Patient Participation } \\
\text { in Patient Safety - An } \\
\text { Exploratory of } \\
\text { Promoting Factors }\end{array}$ & $\begin{array}{l}\text { Journal of } \\
\text { Nursing } \\
\text { Management }\end{array}$ & EBSCOhost & $\begin{array}{l}\text { Q1 pada } \\
\text { Leadership and } \\
\text { Management }\end{array}$ \\
\hline
\end{tabular}


Tabel 1. Identitas Jurnal (lanjutan)

\begin{tabular}{|c|c|c|c|c|c|}
\hline No. & Nama dan Tahun & Judul Artikel & Nama Jurnal & $\begin{array}{l}\text { Database } \\
\text { Elektronik }\end{array}$ & $\begin{array}{c}\text { Kualifikasi } \\
\text { Jurnal }\end{array}$ \\
\hline 4. & $\begin{array}{l}\text { Jee in Hwang, } \\
\text { Sung Wan Kim, } \\
\text { Ho Jun Chin } \\
(2019)\end{array}$ & $\begin{array}{l}\text { Patient Participation } \\
\text { in Patient Safety and } \\
\text { Its Relationship with } \\
\text { Nurses' Patient- } \\
\text { Centered Care } \\
\text { Competency, } \\
\text { Teamwork, and } \\
\text { Safety Climate } \\
\end{array}$ & $\begin{array}{l}\text { Asian Nursing } \\
\text { Research }\end{array}$ & ScienceDirect & $\begin{array}{l}\text { Q2 pada } \\
\text { Medicine } \\
\text { (Miscellaneous) }\end{array}$ \\
\hline
\end{tabular}

Tabel 2. Matriks Ide Pokok Pikiran

\begin{tabular}{lcc}
\hline No. & $\begin{array}{c}\text { Sumber } \\
\text { (penulis dan tahun) }\end{array}$ & Deskripsi topik / isu \\
\hline
\end{tabular}

1. Merja Sahlstrom, Pirjo Penelitian ini menyimpulkan faktor yang Partanen, Cheryl Rathert, mempengaruhi partisipasi pasien dalam keselamatan, Hannele Turunen (2016) antara lain: pengetahuan pasien mengenai keselamatan pasien, persepsi pasien mengani partisipasi pasien, status kesehatan pasien, sikap pasien terhadap partisipasi, perawat yang menerapkan model PatientCentered care, dan ketidakseimbangan kekuatan.

2. Mona Ringdal, Wendy Chaboyer, Kerstin Ulin, Tracey Bucknall, Lena Oxelmark (2017)

3. Merja Sahlstrom, Pirjo Partanen, Mina Azimirad, Tuomas Selander, Hannele Turunen (2019)

4. Jee in Hwang, Sung Wan Kim, Ho Jun Chin (2019)
Penelitian ini menyimpulkan faktor yang mempengaruhi partisipasi pasien dalam keselamatan pasien natara lain: pengetahuan pasien mengenai keselamatan pasien, persepsi pasien mengenai partisipasi, status kesehatan pasien, perawat yang menerapkan model Patient-Centered Care, dan ketidakseimbangan kekuatan.

Penelitian ini menyimpulkan bahwa faktor yang mempengaruhi partisipasi pasien dalam keselamatan pasien adalah: pengalaman pasien mengenai kesalahan berpengaruh pada partisipasi pasien dalam keselamatan pasien, perawat yang menerapkan model Patient-Centered care, dan pertukaran informasi yang dilakukan perawat.

Penelitian ini menemukan faktor yang mempengaruhi partisipasi pasien dalam keselamatan pasien adalah perawat yang menerapkan Model Patient-Centered Care dan iklim keselamatan dalam lingkungan kerja.

Tabel 3. Matriks Sintesis Artikel

\begin{tabular}{llll}
\hline No. & \multicolumn{1}{c}{ Ide Pokok } & \multicolumn{1}{c}{ Kesamaan Temuan } & \multicolumn{1}{c}{ Sumber } \\
\hline 1. & Partisipasi pasien dalam & Menilai partispasi pasien & Sumber 2 dan 3 \\
& keselamatan pasien & $\begin{array}{l}\text { dalam keselamatan pasien } \\
\text { melalui sudut pandang pasien }\end{array}$ & \\
\cline { 3 - 4 } & & $\begin{array}{l}\text { Menilai partipasi pasien } \\
\text { melalui sudut pandang perawat }\end{array}$ & Sumber 1 dan 4 \\
\hline
\end{tabular}

Tabel 3. Matriks Sintesis Artikel (lanjutan) 


\begin{tabular}{|c|c|c|c|}
\hline No. & Ide Pokok & Kesamaan Temuan & Sumber \\
\hline \multirow[t]{5}{*}{2.} & \multirow[t]{5}{*}{$\begin{array}{l}\text { Faktor yang } \\
\text { mempengaruhi dari sisi } \\
\text { pasien }\end{array}$} & $\begin{array}{l}\text { Pengalaman pasien mengenai } \\
\text { kesalahan berpengaruh pada } \\
\text { partisipasi pasien dalam } \\
\text { keselamatan }\end{array}$ & Sumber 3 \\
\hline & & $\begin{array}{l}\text { Pengetahuan pasien mengenai } \\
\text { keselamatan pasien }\end{array}$ & Sumber 1 dan 2 \\
\hline & & $\begin{array}{l}\text { Persepsi pasien mengenai } \\
\text { partisipasi (motivasi dan } \\
\text { minat) }\end{array}$ & Sumber 1 dan 2 \\
\hline & & $\begin{array}{l}\text { Status kesehatan pasien } \\
\text { (kemampuan fisik dan mental, } \\
\text { serta kondisi) }\end{array}$ & Sumber 1 dan 2 \\
\hline & & $\begin{array}{l}\text { Sikap pasien terhadap } \\
\text { partisipasi }\end{array}$ & Sumber 1 \\
\hline \multirow[t]{4}{*}{3.} & \multirow[t]{4}{*}{$\begin{array}{l}\text { Faktor yang } \\
\text { mempengaruhi dari sisi } \\
\text { perawat }\end{array}$} & $\begin{array}{l}\text { Perawat yang menerapkan } \\
\text { model Patient Centered care } \\
\text { (menghormati, memfasilitasi, } \\
\text { mendorong pasien, dan } \\
\text { memberdayakan pasien untuk } \\
\text { berpartisipasi) }\end{array}$ & Sumber $1,2,3$, dan 4 \\
\hline & & $\begin{array}{l}\text { Pertukaran informasi yang } \\
\text { dilakukan perawat }\end{array}$ & Sumber 3 \\
\hline & & $\begin{array}{l}\text { Iklim keselamatan dalam } \\
\text { lingkungan kerja }\end{array}$ & Sumber 4 \\
\hline & & $\begin{array}{l}\text { Ketidakseimbangan kekuatan } \\
\text { (patrenalistik, budaya } \\
\text { tradisional) }\end{array}$ & Sumber 1 dan 2 \\
\hline
\end{tabular}

\section{DAFTAR PUSTAKA}

Berger, Z., Flickinger, T. R., Pfoh, E., Martinez, K. A., Dy, S. M., (2013). Promoting engagement by patients and families to reduce adverse events in acute care setting: a systematic review. BMJ Qual. Saf. 23(7), 548-555. doi: 10.1136/bmjqs-2012-001769

Castro, E. M., Regenmortel, T. V., Vanhecht, K., Sermeus, W., Hecke, A.V. (2016). Patient empowerment, patient participation and patientcenteredness in hospital care: A concept analysis based on a literature review. Patient Educ. Couns. 99: 1923-39.

Coulter, A., \& Ellins, J., 2007.
Effectiveness of strategies for informing, educating, and involving patients. Br. Med. J. 335 (7609), 2427 , doi: 10/1136/bmj.39246.581169.80.

Davis, R. E., Jacklin, R., Sevdalis, N., \& Vincent, C. A. (2007). Patient involvement in patient safety: What Factors Influence Patient Participation and Engagement?" Health Expectations 10(3): 259-67.

Dudas, K., Olsson, L., Wolf, A., Swedherg, K., Taft, C., Schaufelberger, M., \& Ekman, I., 2013. Uncertainty in illness among patients with chronic heart failure is less in person-centred care than in usual care. Eur. J. Cardiovasc. Nurs. 12(6), 521-528. doi: 


\section{$10.1177 / 1474515112472270$}

Dwamena, F., Holmes-Rovner, M., Gaulden, C. M., Jorgenson, S., Sadigh, G., Sikorsii, A., Lewin. S., Smith, R. C., Coffey, J., \& Olomu, A. (2012). Intervention for providers to promote a patient-centered approach in clinical consultations. Cochrane Database Systematic Review, 12 (12), CD003267 doi: 10.1002/14651858.CD003267.pub2

Ekman, I., Wolf, A., Olsson, L., Taft, C., Dudas, K., Schaufelberger, M., \& Swedberg, K. (2012). Effects of person-centred care in patients with chronic heart failure: The PCC-HF study. Eur. Heart J. 33 (9), 11121119. doi: 10.1093/eurheartj/ehr306

Hall, J., Peat, M., Birks, Y., Golder, S., Entwistle, V., Gilbody, S., Mansell, P., McCaughan, D., Sheldon, T., Watt, I., Williams, B., \& Wright, J. (2010). Effectiveness of interventions designed to promote patient involvement to enhance safety: A systematic review. Qual Saf health Care 19(5), e10. doi: 10.1136/qshc.2009.032748.

Ho“ glund, A. T., Winblad, U., Arnetz, B., Arnetz, J. E., 2010. Patient participation during hospitalization for myocardial infarction: perceptions among patients and personnel. Scand. J. Caring Sci. 24 (3), 482-489. doi: 10.1111/j.1471-6712.2009.00738.x

Hor, S., Godbold, N., Collier, A., \& Iedema, R. (2013). Finding the patient in patient safety. Health (United Kingdom) 17(6): 567-83.

Hovey, R. B., Morck, A., Nettleton, S., Robin, S., Bullis, D., Findlay, A. .... Massfeller, H. (2010). Partners in our care: patient safety from a patient perspective. Quality and Safety in Health Care, 19(6), 1-4. doi: 10.1136/qshc.2008.030908.

Hwang, J., Kim, S. W., \& Chin, H. J. (2019). Patient participation in patient safety and its relationships with nurses' patient-centered care competency, teamwork, and safety climate. Asian Nursing Research, 13(2), 130-36. doi: 10.1016/j.anr.2019.03.001.

Joseph-Williams, N., Elwyn, G., \& Edwards, A. (2014). Knowledge is not power for patients: A systematic review and thematic synthesis of patient-reported barriers and facilitators to shared decision Making. Patient Education and Counseling 94(3): 291-309.

Longtin, Y., Sax, H., Leape, L. L., Sheridan, S. E., Donaldson, L., \& Pittet, D. (2010). Patient participation: Current knowledge and applicability to patient safety. Mayo Clinic Proceedings, 85(1): 53-62. doi: $10.4065 / \mathrm{mcp} .2009 .0248$.

Peat, M., Entwistle, V., Hall, J., Birks, Y., \& Golder, S., 2010. Scoping review and approach to appraisal of interventions intended to involve patients in patient safety. J. Health Serv. Res. Policy, 15(1), 17-25. doi: 10.1258/jhsrp.2009.009040

Ringdal, M., Chaboyer, W., Ulin, K., Bucknall, T., \& Oxelmark, L. (2017). Patient preferences for participation in patient care and safety activities in hospitals. BMC Nursing 16(1): 1-8.

Sahlström, Merja et al. 2019. "Patient Participation in Patient Safety-An Exploration of Promoting Factors." Journal of Nursing Management 27(1): 84-92.

Sahlström, M., Partanen, P., Rathert, C., \& Turunen, H. (2016). Patient 
participation in patient safety still missing: Patient safety experts' views. International Journal of Nursing Practice, 22(5), 461-69. doi: 10.1111/ijn.12476.

Schwappach, D. L.B., Frank, O., \& Hochreutener, M. A. 2011. 'New perspectives on well-known issues': Patients' experiences and perceptions of safety in Swiss hospitals. Zeitschrift fur Evidenz, Fortbildung und Qualitat im Gesundheitswesen 105(7): 542-48. doi: org/10.1016/j.zefq.2010.07.002

Silfa, A. B., Hardisman, \& Pabuti, A. (2018). Hubungan pengetahuan dan persepsi pasien dengan partisipasi pasien di Instalasi Paviliun Ambun Pagi RSUP DR. M. Djamil Padang ditinjau dari aspek hukum keselamatan pasien. Jurnal Kesehatan Andalas, 7(2): 160-69.

Slatore, C. G., (2010). Patient-clinician communication: Associations with important health outcomes among veterans with COPD. Chest, 138 (3), 628-634. doi: 10.1378/chest.09-2328

Vaismoradi, M., Jordan, S., \& Kangasniemi, M. (2015). Patient participation in patient safety and nursing input - a systematic review. Journal of Clinical Nursing, 24(5-6): 627-39. doi: 10.1111/jocn.12664

Vincent C. A., \& Coulter, A. (2002). Patient safety: what about the patient? Quality and Safety in Health Care, 11(1), 76-80. doi: 10.1136/qhe.11.1.76.

Weingart, S. N., Zhu, J., Chiappetta, L., Stuver, S. O., Schneider, E. C., Epstein, A. M., David-Kasdan, J. A., ... Weissman, J. S., (2011). Hospitalized patients' participation and its impact on quality of care and patient safety. Int. J. Qual. Health Care, 23 (3), 269-277. doi: 10.1093/intqhe/mzr002.

WHO. (2013). Exploring patient participation in reducing health-carerelated safety risks. Diperoleh dari https://www.euro.who.int/en/publicati ons/abstracts/exploring-patientparticipation-in-reducing-health-carerelated-safety-risks 